\title{
An Open Pilot Study Exploring the Efficacy of Fluvastatin, Pegylated Interferon and Ribavirin in Patients with Hepatitis C Virus Genotype $\mathbf{1 b}$ in High Viral Loads
}

\author{
Hitomi Sezaki ${ }^{a}$ Fumitaka Suzuki $^{a}$ Norio Akuta ${ }^{a}$ Hiromi Yatsuji ${ }^{a}$ \\ Tetsuya Hosaka ${ }^{a}$ Masahiro Kobayashi ${ }^{a}$ Yoshiyuki Suzuki ${ }^{a}$ Yasuji Arase ${ }^{a}$ \\ Kenji Ikeda ${ }^{a}$ Yuzo Miyakawa $^{\mathrm{b}}$ Hiromitsu Kumada $^{\mathrm{a}}$ \\ ${ }^{\mathrm{a}}$ Department of Hepatology, Toranomon Hospital, and ${ }^{\mathrm{b}}$ Miyakawa Memorial Research Foundation, Tokyo, Japan
}

\section{Key Words}

Hepatitis, chronic - Virus, hepatitis C · Statin - Interferon, pegylated $\cdot$ Ribavirin

\begin{abstract}
Objective: Response to pegylated (PEG) interferon (IFN) and ribavirin is achieved only in $40-50 \%$ of patients infected with hepatitis $C$ virus (HCV) of genotype 1 in high viral loads, which needs to be improved. Methods: In an open-label pilot study, fluvastatin (HMG-CoA reductase inhibitor), $20 \mathrm{mg}$ daily, was given along with PEG-IFN/ribavirin to 21 patients with chronic hepatitis $C$. They were followed for HCV RNA in serum. Results: During treatment for 48 weeks, HCV RNA was lost from serum in $93 \%$ of the patients. In the 15 patients who received 48-week therapy, a sustained virological response (SVR) with loss of HCV RNA 24 weeks after completion was achieved in 10 (67\%), including 7 of the 9 (78\%) male and 3 of the $6(50 \%)$ female patients. In the remaining 6 patients who received 72-week therapy, SVR was gained in 4 (67\%), including 1 of the 2 male and 3 of the 4 female patients aged 56, 58 and 62 years, respectively. Conclusion: Fluvastatin could be used safely to increase the response to PEGIFN and ribavirin, especially in aged women who respond poorly to combined PEG-IFN/ribavirin.
\end{abstract}

Copyright $\odot 2009$ S. Karger AG, Basel

\section{Introduction}

Over the world approximately 190 million people are persistently infected with hepatitis C virus (HCV) [1], and about $30 \%$ of them develop serious liver disease such as decompensated cirrhosis and hepatocellular carcinoma (HCC) [2]. Interferon (IFN) is the only drug that can resolve HCV infection. However, using the most advanced treatment currently available, with pegylated (PEG)-IFN and ribavirin for 24-48 weeks, a sustained virological response (SVR) defined by the loss of HCV RNA from serum 24 weeks after completion of therapy is achieved in $40-80 \%$ of the patients [3-5]. The response rate is influenced by host factors such as sex, age and ethnicity [6-8], as well as virological factors including genotypes and viral loads [9]. It remains unsatisfactorily low in patients infected with HCV genotype 1 at merely $40-$ $50 \%$, and dismal in women aged 50 years or older at merely $22 \%$ [10]. Hence, there is an imminent need to improve the efficacy of antiviral treatment for terminating $\mathrm{HCV}$ infection in these patients.

Efforts have been devoted toward increasing the efficacy to PEG-IFN/ribavirin therapy. Inhibitors of viral protease, alone or in combination with the IFN-based treatment, have been found effective in preliminary studies $[11,12]$. Recently, drugs that can inhibit the key enzyme

\section{KARGER}

Fax +41613061234 E-Mail karger@karger.ch www.karger.com (c) 2009 S. Karger AG, Basel

$0300-5526 / 09 / 0521-0043 \$ 26.00 / 0$

Accessible online at:

www.karger.com/int
Hitomi Sezaki, MD

Department of Hepatology, Toranomon Hospital

Minato-ku

Tokyo 105-8470 (Japan)

Tel. +81 44877 5111, Fax +81 44860 1623,E-Mail hitomis@mx1.harmonix.ne.jp 
for controlling the synthesis of cholesterol, 3-hydroxy-3methylglutaryl (HMG)-CoA reductase, have gained attention due to their potential to decrease the replication of HCV in clinical and experimental settings [13, 14].

More than three quarters of Japanese patients are infected with HCV genotype $1 \mathrm{~b}$ in high viral loads. They are much older than Western patients owing to the widespread HCV infection which struck Japan about 20 years ago [15]. Owing to this, the response to PEG-IFN/ribavirin in Japanese patients with chronic hepatitis $\mathrm{C}$ is poorer than that in Western countries. In an open-label pilot study, 21 patients with chronic hepatitis C, who were infected with HCV-1b at high viral loads, received triple treatment with fluvastatin, PEG-IFN and ribavirin. Ontreatment viral dynamics and SVR achieved by the triple therapy could offer hope for improving the response in patients infected with HCV-1 in high viral loads.

\section{Patients and Methods}

From December 2005 to March 2006, 21 patients with chronic hepatitis $\mathrm{C}$ agreed to receive fluvastatin, in addition to standard PEG-IFN/ribavirin treatment, at the Department of Hepatology, Toranomon Hospital, Metropolitan Tokyo. They all were: (1) positive for antibody to HCV (anti-HCV) and HCV RNA of genotype $1 \mathrm{~b}$, and not co-infected with HCV of the other genotypes; (2) negative for hepatitis B surface antigen or antibody to human immunodeficiency virus type-1 (HIV-1); (3) confirmed within the past 2 months to have high HCV RNA levels of $\geq 100 \mathrm{KIU} / \mathrm{ml}$, which is the Japanese definition of high viral loads [16, 17]; (4) platelet counts $>80 \times 10^{3} / \mathrm{mm}^{3}$ and without cirrhosis diagnosed by ultrasonography; (5) body weight $>40 \mathrm{~kg}$ and not pregnant or lactating; (6) a total alcohol intake of $<500 \mathrm{~kg}$ during the past; (7) without HCC, hemochromatosis, Wilson's disease, primary biliary cirrhosis, alcoholic hepatitis or autoimmune hepatitis; (8) without antiviral or immunosuppressive treatment during the previous 3 months, and (9) with the wish to comply to the treatment protocol for 48-72 weeks.

They were followed for liver function and virological markers at least monthly during treatment and until 24 weeks after completion of triple treatment. Informed consent was obtained from each patient, and the study protocol conforms to the ethical guidelines of the 1975 Declaration of Helsinki as reflected in a priori approval by the institution's human research committee.

\section{Markers of HCV Infection}

Anti-HCV was determined by third-generation enzymelinked immunosorbent assay (ELISA) using commercial kits (Ortho HCV Ab ELISA Test 3; Chiron Cooperation, Emeryville, Calif., USA). HCV RNA was determined quantitatively by polymerase chain reaction (PCR; Cobas Amplicor HCV Monitor ver. 2.0, Roche Diagnostics, Tokyo, Japan), with a dynamic range from 5 to $5,000 \mathrm{KIU} / \mathrm{ml}$, in sera diluted 10 -fold at baseline, as well as every 2 weeks until 8 weeks after initiation of therapy and monthly thereafter. Sera negative for HCV RNA $(<5 \mathrm{KIU} / \mathrm{ml})$ by the quantitative assay were tested by qualitative PCR (Amplicor, Roche Molecular Systems, Inc., Branchburg, N.J., USA) with the detection limit at 100 copies $/ \mathrm{ml}$.

Fluvastatin Added to Combined PEG-IFN and Ribavirin

Patients received subcutaneous PEG-IFN- $\alpha 2 b$ (PEG-Intron, Schering-Plough Corp., Kenilworth, N.J., USA) weekly at a median dose of 1.5 (range 1.3-1.7) $\mu \mathrm{g} / \mathrm{kg}$, along with oral ribavirin daily at a median dose of 12.3 (range 10.2-13.7) $\mathrm{mg} / \mathrm{kg}$ for $48-72$ weeks. The dose of ribavirin was adjusted according to body weight: 600 $\mathrm{mg}$ for patients weighing $\leq 60 \mathrm{~kg} ; 800 \mathrm{mg}$ for those between $>60$ and $<80 \mathrm{~kg}$, and $1,000 \mathrm{mg}$ for those $\geq 80 \mathrm{~kg}$. In addition, the patients received $20 \mathrm{mg}$ oral fluvastatin daily for 48-72 weeks.

\section{Results}

Patients Who Received Triple Treatment with Fluvastatin, PEG-IFN and Ribavirin

The baseline characteristics of the 21 patients infected with HCV-1b at a high viral load and who received triple therapy with fluvastatin, PEG-IFN and ribavirin are listed in table 1 . Their median age was 56 years, and 11 (52\%) were men. Their hematological and biochemical values including serum lipids were within normal limits, except for elevated levels of AST and ALT. A lack of mutations affecting the response to IFN in the core protein, i.e., mutations at positions 70 and 91 [16], and amino acid substitutions in the IFN-sensitivity determining region [18] were detected in HCV RNA from 29 and 35\% of the patients.

\section{Loss of HCV RNA from Serum in Patients with Triple Treatment}

Figure 1 illustrates the cumulative loss of HCV RNA from the serum in 21 patients infected with HCV-1b at high loads. HCV RNA was cleared in $52 \%$ of the patients during the first 12 weeks. It decreased slowly thereafter, and was lost in $93 \%$ of the patients at 48 weeks. Triple treatment was continued in 6 of the 21 patients for an additional 24 weeks. HCV RNA was cleared from the serum in $5(83 \%)$ of them at completion of the 72 -week treatment.

\section{Sustained Virological Response in Patients Receiving Triple Treatment}

Of the 21 patients given triple treatment, 19 received it for 48 weeks. Skin rashes and general malaise developed in 2 of them at weeks 17 and 24, respectively, and fluvastatin was withdrawn while PEG-IFN and ribavirin were continued. Six patients continued to receive triple treatment for an additional 24 weeks. Therefore, the loss of HCV RNA from the serum 24 weeks after completion of 
Table 1. Baseline characteristics of patients $(n=21)$ with chronic hepatitis $\mathrm{C}$ who received triple treatment with fluvastatin, PEGIFN and ribavirin

\begin{tabular}{lcc}
\hline & $\begin{array}{c}\text { Normal } \\
\text { ranges }\end{array}$ & Patients \\
\hline Age, years & NA & $56(32-63)$ \\
Men & NA & $11(52 \%)$ \\
Albumin, g/dl & $3.9-5.2$ & $3.8(3.4-4.2)$ \\
Hemoglobin, g/dl & $11.3-17.0$ & $14.4(12.1-16.4)$ \\
Platelets, $\times 10^{3} / \mathrm{mm}^{3}$ & $141-350$ & $190(119-240)$ \\
AST, IU/l & $13-33$ & $50(21-208)$ \\
ALT, IU/l & $6-42$ & $64(23-391)$ \\
$\gamma$-GTP & $9-109$ & $36(11-301)$ \\
ICG $15, \%$ & $<10$ & $12(2-27)$ \\
HCV RNA, KIU/ml & NA & $2,000(14->5,000)$ \\
Past treatments & NA & $8(36 \%)$ \\
Ribavirin dose, mg/kg & NA & $12.3(10.2-13.7)$ \\
Serum lipids & & \\
Total cholesterol, mg/dl & $122-240$ & $163(124-273)$ \\
$\quad$ LDL-C, mg/dl & $86-160$ & $99(59-187)$ \\
$\quad$ HDL-C, mg/dl & $35-75$ & $46(28-73)$ \\
Mutations in HCV RNA & & \\
$\quad$ Wild-type at aa70 & NA & $12(57 \%)$ \\
$\quad$ Wild-type at aa91 & NA & $10(48 \%)$ \\
Double wild, aa71/aa90 & NA & $6(29 \%)$ \\
$\quad$ Mutations in ISDR & NA & $6 / 17(35 \%)$ \\
\hline
\end{tabular}

Data are expressed as the number of patients with percentages in parentheses or median values with ranges in parentheses. AST $=$ Aspartate aminotransferase; ALT $=$ alanine aminotransferase; $\gamma$-GTP $=\gamma$-glutamyltranspeptidase; $\mathrm{ICG}_{15}=$ retention of indocyanine green at $15 \mathrm{~min}$; LDL-C = low-density lipoprotein cholesterol; HDL-C = high-density lipoprotein cholesterol; NA = not applicable.

therapy was assessed in the remaining 15 patients. Figure 2 shows the SVR in 15 patients. SVR was accomplished in $10(67 \%)$ of them, including 7 of $9(78 \%)$ male patients and 3 of $6(50 \%)$ female patients. Of the 5 female patients aged $>50$ years, $2(40 \%)$ gained SVR.

Of the 6 patients who received triple treatment for 72 weeks, SVR was accomplished in 4 (67\%), including 1 of 2 male and 3 of 4 female patients who were aged 56, 58 and 62 years, respectively.

\section{Discussion}

Statins comprise a group of drugs capable of inhibiting HMG-CoA reductase and can regulate the synthesis of cholesterol by competing with the authentic substrate $[19$,

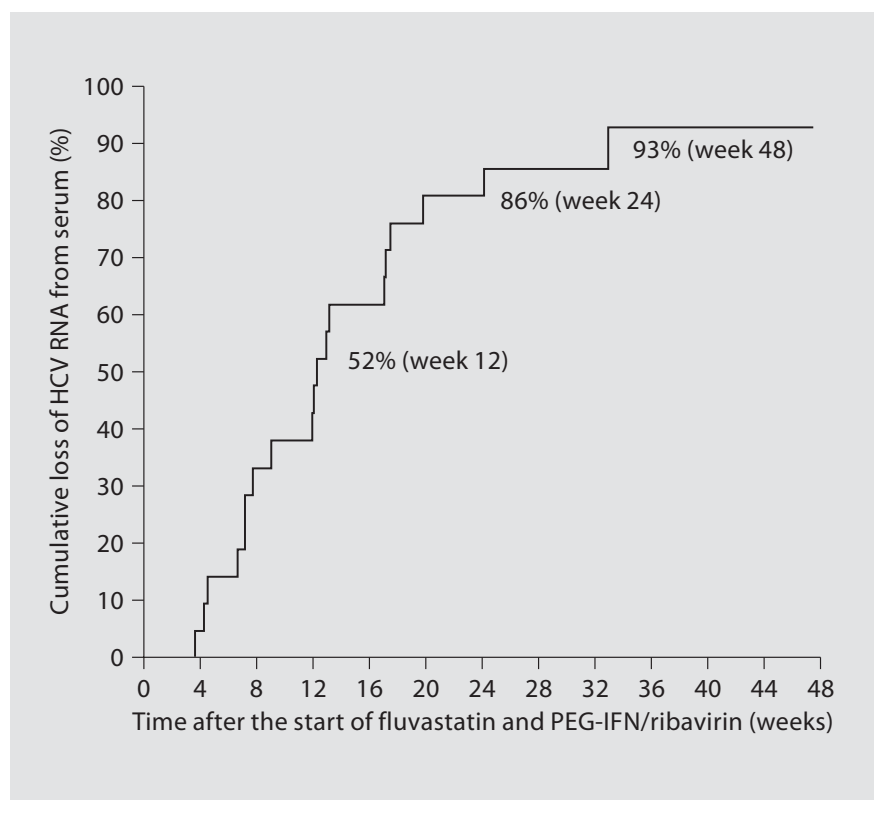

Fig. 1. Kaplan-Meier table illustrating the cumulative loss of $\mathrm{HCV}$ RNA from the serum in patients with chronic hepatitis $C$. The patients received fluvastatin in addition to PEG-IFN/ribavirin and were followed during 48 weeks of treatment.

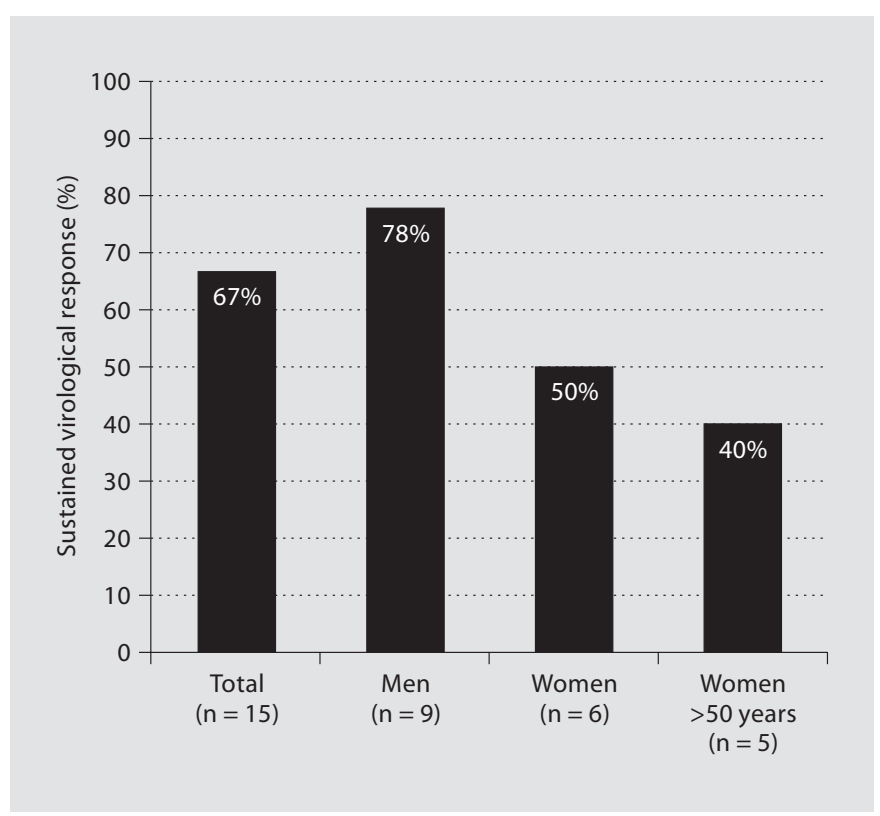

Fig. 2. Sustained virological response in patients with chronic hepatitis $\mathrm{C}$ to the combined treatment with fluvastatin, PEG-IFN and ribavirin for 48 weeks. SVR was compared among the total, male and female patients, as well as the female patients aged more than 50 years. 
20]. They are the best selling drugs in the world, and have been prescribed to more than 30 million patients for lowering serum levels of low-density lipoprotein cholesterol (LDL-C) with the main purpose of preventing cardiovascular accidents $[21,22]$. The great virtue of statins is their excellent safety record. Recipients are rarely forced to discontinue statins due to mild side effects including myalgia, headache and skin rashes, thereby allowing their long-term use to be extended to decades and even for life. Liver toxicity is found in less than $1.2 \%$ of 49,275 patients with a history of cardiovascular disease [23].

In transfection experiments of cultured hepatocytes, statins inhibited the replication of HCV in synergism with IFN- $\alpha$ [14]. Of particular note, the extent of inhibition differs among various statins, and is highest for lipophilic fluvastatin and lowest for hydrophilic pravastatin. In clinical studies, monotherapy with fluvastatin suppressed serum HCV RNA by $\log 1.75$ at a daily therapeutic dose of $<80 \mathrm{mg}$ [13], while no such effects were gained with $20 \mathrm{mg}$ atorvastatin daily [24]. Hence, the ability to inhibit HCV replication may differ among diverse statins through mechanisms not directly associated with lowered levels of LDL-C; fluvastatin decreases total cholesterol and LDL-C levels to a lesser extent than the other statins in current use.

In this open-label pilot study, the response to triple treatment with fluvastatin $20 \mathrm{mg}$ daily supplementing the standard PEG-IFN/ribavirin was examined in $21 \mathrm{pa-}$ tients infected with HCV-1b in high loads. The cumulative loss of HCV RNA from the serum was gained in $93 \%$ of the patients after they had received triple treatment for 48 weeks. Only 2 of the 21 (10\%) patients did not tolerate fluvastatin due to skin rashes and general malaise. The triple treatment was continued for 72 weeks in 6 patients to determine its long-term effects. SVR was achieved in 10 of $15(67 \%)$ patients on the 48 -week schedule, including 7 of $9(78 \%)$ male patients and 3 of $6(50 \%)$ female patients. Of the 5 female patients aged $>50$ years, $2(40 \%)$ gained SVR. Of the 6 patients who received triple treatment for 72 weeks, 4 (67\%) achieved SVR, including 1 of 2 male and 3 of 4 female patients who were aged 56, 58 and 62 years, respectively. SVR gained by triple treatment with fluvastatin, PEG-IFN and ribavirin for 48 weeks $(67 \%)$ is better than that 80 of $160(50 \%)$ and 55 of 118 (47\%) patients who received PEG-IFN and ribavirin for 48 weeks $[16,25]$; they all were infected with HCV-1b at high loads.

Sex and age are the two principal host factors influencing the response to IFN-based treatment. Although women respond better to combined IFN and ribavirin than men in large-scale multinational studies in Western countries $[8,26]$, target patients were rather young with the median age of about $40-41$ years. Sex-dependent responsiveness to IFN is reversed with age, however, and the response to PEG-IFN/ribavirin is much poorer in female than male patients aged 50 years or older $(22 / 100$ [22\%] vs. 50/94 [53\%], p <0.001) [10]. In view of the estradiols that can prohibit fibrosis in experimental cirrhosis induced in rats [27], levels of female sex hormones, which are lower in women than men older than 50 years [28], could be responsible for the sex difference in response to IFN of patients with chronic hepatitis C. Supplementation of aged female patients with estradiols may increase the response, but it can accelerate physiological osteoporosis $[29,30]$. Since statin therapy does not increase the risk of severe hepatotoxicity in patients with chronic hepatitis C [31], fluvastatin may provide aged women with an advantage in gaining SVR to PEG-IFN/ribavirin. Furthermore, fluvastatin does not augment the side effects of other drugs, such as cyclosporine A and warfarin, because it is metabolized by CYP2C9 in the liver, unlike other statins that are disposed by CYP3A4 as other drugs [32].

Should statins interfere with the replication of HCV, it remains an open question how they do it. At least three mechanisms may be conceived for the decrease in $\mathrm{HCV}$ replication in patients receiving statins. $\mathrm{HCV}$ circulates in association with LDL-C [33], and on that basis, the LDL-C receptor has been proposed for infection of hepatocytes [34-36]. HCV RNA replicates in association with lipid droplets in hepatocytes [37, 38], and therefore, the synthesis of cholesterol blocked by statins can reduce the basis on which HCV thrives. However, these two scenarios seem to stand at odds with the response to IFN being better in patients with higher LDL-C levels [39, 40]. Statins prohibit the synthesis of mevalonate that is modified into geranylgeranyl (containing 20 carbons) and then farnesyl (15 carbons) [19]. They both prenylate most cellular proteins to make them lipophilic toward associations with membranes expressing their biological activities [41]. As an extension to these, the geranylgeranylation of host proteins, which may be required for the replication of $\mathrm{HCV}$, is implicated in the capacity of statins to downregulate HCV infection [42-44]. For that matter, most pleiotropic effects of statins, including a deceased incidence of dementia and Alzheimer disease [45-47], could be associated with the inhibition of prenylation rather than lowered levels of LDL-C in the serum [48]. 
This study is not without limitations. The number of patients receiving fluvastatin along with PEG-IFN and ribavirin is small and fails to gain statistical power in any comparison with those given PEG-IFN/ribavirin in previous studies. The ability of other statins in improving the response to PEG-IFN/ribavirin has not been examined to discover the mechanism of how fluvastatin improves the response to antiviral treatments. The promising results obtained in this study hopefully will invite further interest for planning clinical trials with extended numbers of patients and targeting elderly women in par- ticular. Meanwhile, it may be worth looking back in the database to examine the response of patients receiving PEG-IFN/ribavirin for chronic hepatitis C, simultaneously with statins for controlling LDL-C levels, to see if they fared better than those not taking statins routinely.

\section{Acknowledgment}

This study was supported in part by grants from Okinaka Memorial Foundation in Toranomon Hospital of Japan.

\section{References}

1 Cohen J: The scientific challenge of hepatitis C. Science 1999;285:26-30.

2 Seeff LB: Natural history of chronic hepatitis C. Hepatology 2002;36:S35-S46.

3 Fried MW, Shiffman ML, Reddy KR, Smith C, Marinos G, Goncales FL Jr, Haussinger D, Diago M, Carosi G, Dhumeaux D, Craxi A, Lin A, Hoffman J, Yu J: Peginterferon alfa-2a plus ribavirin for chronic hepatitis $C$ virus infection. N Engl J Med 2002;347:975-982.

-4 Hadziyannis SJ, Sette H Jr, Morgan TR, Balan V, Diago M, Marcellin P, Ramadori G, Bodenheimer H Jr, Bernstein D, Rizzetto M, Zeuzem S, Pockros PJ, Lin A, Ackrill AM: Peginterferon-alpha2a and ribavirin combination therapy in chronic hepatitis $\mathrm{C}$ : a randomized study of treatment duration and ribavirin dose. Ann Intern Med 2004;140: 346-355.

- 5 Manns MP, McHutchison JG, Gordon SC, Rustgi VK, Shiffman M, Reindollar R, Goodman ZD, Koury K, Ling M, Albrecht JK: Peginterferon alfa-2b plus ribavirin compared with interferon alfa-2b plus ribavirin for initial treatment of chronic hepatitis $\mathrm{C}$ : a randomised trial. Lancet 2001;358:958-965.

6 Kanwal F, Hoang T, Spiegel BM, Eisen S, Dominitz JA, Gifford A, Goetz M, Asch SM: Predictors of treatment in patients with chronic hepatitis $\mathrm{C}$ infection - role of patient versus nonpatient factors. Hepatology 2007; 46:1741-1749.

7 Poynard T, Bedossa P, Opolon P: Natural history of liver fibrosis progression in patients with chronic hepatitis C. Lancet 1997;349: $825-832$.

-8 Conjeevaram HS, Fried MW, Jeffers LJ, Terrault NA, Wiley-Lucas TE, Afdhal N, Brown RS, Belle SH, Hoofnagle JH, Kleiner DE, Howell CD: Peginterferon and ribavirin treatment in African American and Caucasian American patients with hepatitis $\mathrm{C}$ genotype 1. Gastroenterology 2006;131:470477.
Tsubota A, Chayama K, Ikeda K, Yasuji A, Koida I, Saitoh S, Hashimoto M, Iwasaki S, Kobayashi M, Hiromitsu K: Factors predictive of response to interferon-alpha therapy in hepatitis $\mathrm{C}$ virus infection. Hepatology 1994;19:1088-1094.

10 Sezaki H, Suzuki F, Kawamura Y, Yatuji H, Hosaka T, Akuta N, Kobayashi M, Suzuki Y, Saitoh S, Arase Y, Ikeda K, Miyakawa Y, Kumada H: Poor response to pegylated interferon and ribavirin in aged women infected with hepatitis $C$ virus of genotype $1 b$ in high viral loads. Dig Dis Sci, in press.

11 Lawitz E, Rodriguez-Torres M, Muir AJ, Kieffer TL, McNair L, Khunvichai A, McHutchison JG: Antiviral effects and safety of telaprevir, peginterferon alfa- $2 \mathrm{a}$, and ribavirin for 28 days in hepatitis $\mathrm{C}$ patients. J Hepatol 2008;49:163-169.

12 Forestier N, Reesink HW, Weegink CJ, McNair L, Kieffer TL, Chu HM, Purdy S, Jansen PL, Zeuzem S: Antiviral activity of telaprevir (VX-950) and peginterferon alfa-2a in patients with hepatitis C. Hepatology 2007;46 640-648.

13 Bader T, Fazili J, Madhoun M, Aston C, Hughes D, Rizvi S, Seres K, Hasan M: Fluvastatin inhibits hepatitis $C$ replication in humans. Am J Gastroenterol 2008; 103:13831389.

14 Ikeda M, Abe K, Yamada M, Dansako H, Naka K, Kato N: Different anti-HCV profiles of statins and their potential for combination therapy with interferon. Hepatology 2006; 44:117-125.

15 Yoshizawa H, Tanaka J, Miyakawa Y: National prevention of hepatocellular carcinoma in Japan based on epidemiology of hepatitis $C$ virus infection in the general population. Intervirology 2006;49:7-17.
Akuta N, Suzuki F, Kawamura Y, Yatsuji H, Sezaki H, Suzuki Y, Hosaka T, Kobayashi M, Kobayashi M, Arase Y, Ikeda K, Kumada H: Predictors of viral kinetics to peginterferon plus ribavirin combination therapy in Japanese patients infected with hepatitis $C$ virus genotype 1b. J Med Virol 2007;79:16861695.

17 Sezaki H, Suzuki F, Kawamura Y, Yatsuji H, Hosaka T, Akuta N, Kobayashi M, Suzuki Y, Arase Y, Ikeda K, Kumada H: Evaluation of long-term biochemical responses to combination therapy of interferon plus ribavirin in those infected with hepatitis $\mathrm{C}$ virus genotype $1 \mathrm{~b}$ and high baseline viral load. Hepatol Res 2007;37:787-792.

18 Enomoto N, Sakuma I, Asahina Y, Kurosaki M, Murakami T, Yamamoto C, Ogura Y, Izumi N, Marumo F, Sato C: Mutations in the nonstructural protein $5 \mathrm{~A}$ gene and response to interferon in patients with chronic hepatitis C virus 1b infection. N Engl J Med 1996; 334:77-81.

19 Goldstein JL, Brown MS: Regulation of the mevalonate pathway. Nature 1990;343:425430.

20 Istvan ES, Deisenhofer J: Structural mechanism for statin inhibition of HMG-CoA reductase. Science 2001;292:1160-1164.

-21 Cannon CP, Braunwald E, McCabe CH, Rader DJ, Rouleau JL, Belder R, Joyal SV, Hill KA, Pfeffer MA, Skene AM: Intensive versus moderate lipid lowering with statins after acute coronary syndromes. N Engl J Med 2004;350:1495-1504.

22 Grundy SM, Cleeman JI, Merz CN, Brewer HB Jr, Clark LT, Hunninghake DB, Pasternak RC, Smith SC Jr, Stone NJ: Implications of recent clinical trials for the National Cholesterol Education Program Adult Treatment Panel III Guidelines. J Am Coll Cardiol 2004; 44:720-732.

23 de Denus S, Spinler SA, Miller K, Peterson AM: Statins and liver toxicity: a meta-analysis. Pharmacotherapy 2004;24:584-591. 
-24 O’Leary JG, Chan JL, McMahon CM, Chung RT: Atorvastatin does not exhibit antiviral activity against $\mathrm{HCV}$ at conventional doses: a pilot clinical trial. Hepatology 2007;45: 895-898.

-25 Akuta N, Suzuki F, Kawamura Y, Yatsuji H, Sezaki H, Suzuki Y, Hosaka T, Kobayashi M, Kobayashi M, Arase Y, Ikeda K, Miyakawa Y, Kumada H: Prediction of response to pegylated interferon and ribavirin in hepatitis $\mathrm{C}$ by polymorphisms in the viral core protein and very early dynamics of viremia. Intervirology 2007;50:361-368.

-26 Poynard T, Marcellin P, Lee SS, Niederau C, Minuk GS, Ideo G, Bain V, Heathcote J, Zeuzem S, Trepo C, Albrecht J: Randomised trial of interferon alpha2b plus ribavirin for 48 weeks or for 24 weeks versus interferon alpha2b plus placebo for 48 weeks for treatment of chronic infection with hepatitis C virus. Lancet 1998;352:1426-1432.

-27 Yasuda M, Shimizu I, Shiba M, Ito S: Suppressive effects of estradiol on dimethylnitrosamine-induced fibrosis of the liver in rats. Hepatology 1999;29:719-727.

28 Khosla S, Melton LJ 3rd, Atkinson EJ, O’Fallon WM, Klee GG, Riggs BL: Relationship of serum sex steroid levels and bone turnover markers with bone mineral density in men and women: a key role for bioavailable estrogen. J Clin Endocrinol Metab 1998; 83:2266-2274.

$>29$ Need AG, O'Loughlin PD, Morris HA, Horowitz M, Nordin BE: The effects of age and other variables on serum parathyroid hormone in postmenopausal women attending an osteoporosis center. J Clin Endocrinol Metab 2004;89:1646-1649.

-30 Siris ES, Brenneman SK, Barrett-Connor E, Miller PD, Sajjan S, Berger ML, Chen YT: The effect of age and bone mineral density on the absolute, excess, and relative risk of fracture in postmenopausal women aged 50-99: results from the National Osteoporosis Risk Assessment (NORA). Osteoporos Int 2006; 17:565-574.
-31 Khorashadi S, Hasson NK, Cheung RC: Incidence of statin hepatotoxicity in patients with hepatitis C. Clin Gastroenterol Hepatol 2006;4:902-907.

32 Corsini A, Bellosta S, Baetta R, Fumagalli R, Paoletti R, Bernini F: New insights into the pharmacodynamic and pharmacokinetic properties of statins. Pharmacol Ther 1999; 84:413-428.

33 Andre P, Komurian-Pradel F, Deforges S, Perret M, Berland JL, Sodoyer M, Pol S, Brechot C, Paranhos-Baccala G, Lotteau V: Characterization of low- and very-low-density hepatitis $\mathrm{C}$ virus RNA-containing particles. J Virol 2002;76:6919-6928.

34 Molina S, Castet V, Fournier-Wirth C, Pichard-Garcia L, Avner R, Harats D, Roitelman J, Barbaras R, Graber P, Ghersa P, Smolarsky M, Funaro A, Malavasi F, Larrey D, Coste J, Fabre JM, Sa-Cunha A, Maurel P: The lowdensity lipoprotein receptor plays a role in the infection of primary human hepatocytes by hepatitis C virus. J Hepatol 2007;46:411419.

35 Agnello V, Abel G, Elfahal M, Knight GB Zhang QX: Hepatitis $C$ virus and other flaviviridae viruses enter cells via low density lipoprotein receptor. Proc Natl Acad Sci USA 1999;96:12766-12771.

-36 Monazahian M, Bohme I, Bonk S, Koch A, Scholz C, Grethe S, Thomssen R: Low density lipoprotein receptor as a candidate receptor for hepatitis C virus. J Med Virol 1999;57:223-229.

37 Aizaki H, Lee KJ, Sung VM, Ishiko H, Lai MM: Characterization of the hepatitis $\mathrm{C}$ virus RNA replication complex associated with lipid rafts. Virology 2004;324:450461.

38 Miyanari Y, Atsuzawa K, Usuda N, Watashi K, Hishiki T, Zayas M, Bartenschlager R, Wakita T, Hijikata M, Shimotohno K: The lipid droplet is an important organelle for hepatitis $\mathrm{C}$ virus production. Nat Cell Biol 2007;9:1089-1097.
39 Akuta N, Suzuki F, Kawamura Y, Yatsuji H, Sezaki H, Suzuki Y, Hosaka T, Kobayashi M, Kobayashi M, Arase Y, Ikeda K, Kumada H: Predictive factors of early and sustained responses to peginterferon plus ribavirin combination therapy in Japanese patients infected with hepatitis $C$ virus genotype $1 \mathrm{~b}$ : amino acid substitutions in the core region and lowdensity lipoprotein cholesterol levels. J Hepatol 2007;46:403-410.

40 Gopal K, Johnson TC, Gopal S, Walfish A, Bang CT, Suwandhi P, Pena-Sahdala HN, Clain DJ, Bodenheimer HC Jr, Min AD: Correlation between beta-lipoprotein levels and outcome of hepatitis C treatment. Hepatology 2006;44:335-340.

41 Zhang FL, Casey PJ: Protein prenylation: molecular mechanisms and functional consequences. Annu Rev Biochem 1996;65:241269.

42 Kapadia SB, Chisari FV: Hepatitis C virus RNA replication is regulated by host geranylgeranylation and fatty acids. Proc Natl Acad Sci USA 2005;102:2561-2566.

43 Wang C, Gale M Jr, Keller BC, Huang H, Brown MS, Goldstein JL, Ye J: Identification of FBL2 as a geranylgeranylated cellular protein required for hepatitis $\mathrm{C}$ virus RNA replication. Mol Cell 2005;18:425-434.

-44 Ye J, Wang C, Sumpter R Jr, Brown MS, Goldstein JL, Gale M Jr: Disruption of hepatitis C virus RNA replication through inhibition of host protein geranylgeranylation. Proc Natl Acad Sci USA 2003;100:15865-15870.

45 Wolozin B, Kellman W, Ruosseau P, Celesia GG, Siegel G: Decreased prevalence of Alzheimer disease associated with 3-hydroxy-3methyglutaryl coenzyme A reductase inhibitors. Arch Neurol 2000;57:1439-1443.

46 Jick H, Zornberg GL, Jick SS, Seshadri S, Drachman DA: Statins and the risk of dementia. Lancet 2000;356:1627-1631.

47 Vaughan CJ: Prevention of stroke and dementia with statins: effects beyond lipid lowering. Am J Cardiol 2003;91:23B-29B.

-48 Liao JK, Laufs U: Pleiotropic effects of statins. Annu Rev Pharmacol Toxicol 2005;45:89118. 